\title{
A SUBTLE ELECTROCARDIOGRAPHIC CLUE FOR A MAJOR PROBLEM
}

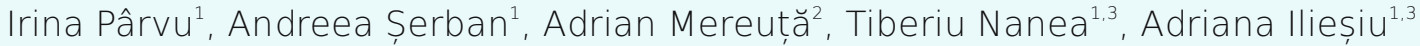 \\ ${ }^{1}$ Spitalul Clinic "Prof. Dr. Th. Burghele", Bucharest \\ ${ }^{2}$ Institutul de Urgență pentru Boli Cardiovasculare "Prof. Dr. CC Iliescu", Bucharest \\ "UMF "Carol Davila", Bucharest \\ Corresponding author: Irina Pârvu \\ Spitalul Clinic "Prof Dr. Th. Burghele" Medicină Internă, Şos. Panduri, Nr.20, Sector 5, \\ Bucharest \\ e-mail: chivuirina@yahoo.com
}

\begin{abstract}
Acute coronary syndromes exhibit rapid and variable ischemic dynamics, with consecutive electrocardiographic changes, sometimes in the absence of angina.

We report the case of a 50 year-old man, admitted for suspected angor de novo, asymptomatic upon admission, and with a normal electrocardiogram. After a few hours, the repeated electrocardiogram displays biphasic T waves in V2-V4, in the absence of symptoms, and then marked ST elevation in the same territory, without chest pain. The patient is transferred with a STEMI diagnosis, and the coronary angiography documents a critical sub-occlusive stenosis in the proximal segment of the left anterior descending artery (LAD), for which a drug-eluting stent is inserted, with a favourable evolution.

Wellens syndrome is defined by characteristic electrocardiographic changes of $T$ waves in leads V2-V4, occurring in the context of unstable angina, usually without pain. They express a critical stenosis in the proximal LAD artery. Recognition of the Wellens syndrome is crucial, as these "pre-infarction" changes tend to evolve, sometimes rapidly, to an extensive anterior myocardial infarction. The rapid and unpredictable ischemic electrocardiographic changes make this case remarkable, as they occur in an asymptomatic patient with unstable angina (angor de novo), thus underlining the need for careful supervision in such patients.
\end{abstract}

Keywords: Wellens, rapid ECG dynamics, unstable angina.

\section{Rezumat}

Sindroamele coronariene acute se caracterizează printr-o dinamică rapidă și variabilă a ischemiei însoțită de modificări electrocardiografice, uneori în absența durerii anginoase.

Prezentăm cazul unui barbat de 50 de ani, spitalizat cu suspiciunea de angor de novo, care la internare era asimptomatic și cu electrocardiograma normală. După câteva ore se decelează 


\section{INTERNAL}

\section{Clinical cases}

pe electrocardiograma de control unde T bifazice în V2 - V4, în absența simptomelor, iar ulterior, supradenivelare ST marcată în același teritoriu, neînsoțită de durere. Bolnavul este transferat cu diagnosticul de STEMI, iar la coronarografie se decelează o stenoză critică, subocluzivă, proximală de interventriculară anterioară (IVA) pentru care se implantează un stent farmacologic activ, cu evoluție favorabilă.

Sindromul Wellens este definit de modificări electrocardiografice caracteristice ale undelor T în derivaţiile precordiale V2 - V4 care apar în context de angină instabilă, de obicei în afara durerii. Ele sunt expresia unei stenoze critice în segmentul proximal al IVA. Recunoașterea sindromului Wellens este crucială, deoarece modificările electrocardiografice de "pre-infarct" sunt evolutive, uneori rapid, către un infarct miocardic anterior întins. Cazul de față ilustrează dinamica electrocardiografică rapidă și imprevizibilă a ischemiei, în absența durerii, la un bolnav cu angină instabilă (angor de novo) și necesitatea supravegherii atente a acestor bolnavi.

Cuvinte cheie: Wellens, dinamică rapidă ECG, angină instabilă.

Ischemia in acute coronary syndromes has a rapid and variable evolution and is associated with electrocardiographic changes (ECG) with or without chest pain.

Under study is the case of a 50-year old man admitted for previous chest pain occurring during the last month. The pain was sporadic, emerging only at rest, with a duration of minutes ceasing spontaneously, suggesting of angor de novo. The patient was smoking 30 packages/year, had hypercholesterolemia, no pathologic personal or heredocollateral medical history and was not under medication.
When admitted the patient presented no symptoms, the ECG was within normal range (Figure 1) and normal values of serum troponin. The clinical examination revealed no pathologic conditions ( $T A=140 / 84 \mathrm{mmHg}$; $\left.A V=72 / \mathrm{min}, \mathrm{BMI}=25.3 \mathrm{~kg} / \mathrm{m}^{2}\right)$, with normal cardiac echography and laboratory tests, except for the high serum cholesterol (Figure 1).

A few hours later, though the patient accused no chest pain, the ECG trajectory was repeated showing a minimum elevation in the ST segment and some biphasic T waves in the precordial leads V2-V4 (compared to the 


\begin{tabular}{|c|c|c|}
\hline Test & Result & Normal range \\
\hline $\mathrm{Hb}$ & 14.8 & $13.1-17.3 \mathrm{~g} / \mathrm{dL}$ \\
\hline $\mathrm{L}$ & 6300 & $4000-10000 / \mathrm{uL}$ \\
\hline $\mathrm{Tr}$ & 233000 & $150000-450000 / \mathrm{uL}$ \\
\hline Glycaemia & 100 & $70-110 \mathrm{mg} / \mathrm{dL}$ \\
\hline Total Cholesterol & 235 & $140-220 \mathrm{mg} / \mathrm{dL}$ \\
\hline LDL-C & 147.2 & $20-170 \mathrm{mg} / \mathrm{dL}$ \\
\hline HDL-C & 74 & $30-75 \mathrm{mg} / \mathrm{dL}$ \\
\hline TG & 71 & $30-200 \mathrm{mg} / \mathrm{dL}$ \\
\hline Serum creatinine & 0.9 & $0.7-1.3 \mathrm{mg} / \mathrm{dL}$ \\
\hline Troponin & 0.01 & $<1 \mathrm{ng} / \mathrm{dL}$ \\
\hline GOT & 22 & $1-37 \mathrm{UI} / \mathrm{L}$ \\
\hline GPT & 23 & $1-41 \mathrm{UI} / \mathrm{L}$ \\
\hline INR & 1.05 & $0.8-1.16$ \\
\hline & & \\
\hline & 23 & 140 \\
\hline
\end{tabular}

Table 1. Laboratory tests

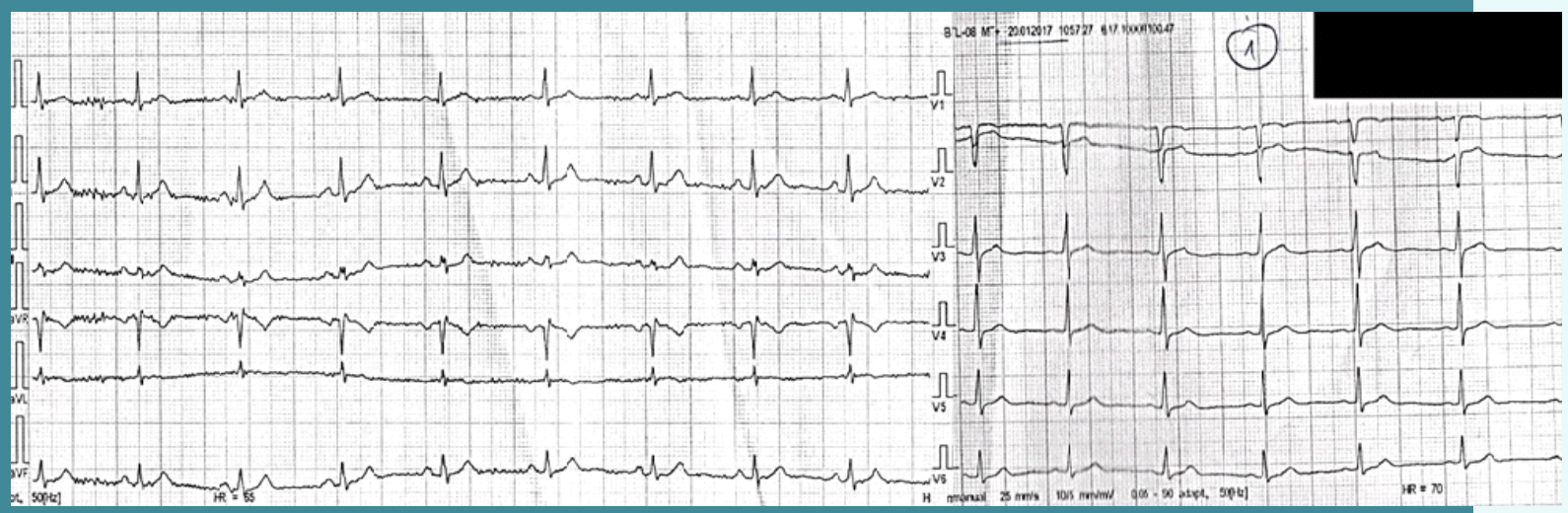

Figure 1. The ECG trajectory when admitted to hospital 
normal ECG trajectory at the moment of his admittance). Due to the electrocardiographic changes the ECG is repeated 20 minutes later, although the patient was completely asymptomatic. This ECG trajectory reveals a significant ST elevation of $10 \mathrm{~mm}$ in leads V2V4, associated with ST elevation in the D1 leads of VL, V2 and V5 (the EKG evolution is shown in Figures 2 and 3), in absence of any symptoms. The ECG changes are interpreted as acute, progressive, anterolateral, transmural ischemia, with elevation in the ST segment for which the patient receives medical treatment consisting in double platelet antiaggregants and high doses of atorvastatin. The patient is immediately transferred to a centre of cardiologic intervention under the suspicion of STEMI. Prior to the coronarographic examination the ECG trajectory regains its normal range (Figure 4) the patient continuing to be asymptomatic, and the myocardial necrosis markers still negative. After revaluating the ECG changes in motion considering the patient's clinical and biological status, the suspected diagnosis was that of coronary spasm.

Nonetheless, the coronary angiography showed a critical, subocclusive, proximal stenosis in the left anterior descending artery (LAD) (Figure 5). A drug-eluting stent was inserted with favourable coronarographic evolution and a TIMI flow 3. Later on, under medical treatment for atherothrombotic disease the immediate and long-term evolution was a favourable one (Figure 6).

\section{Discussions}

The Wellens syndrome, described in the '80s, is also called " $L A D$ coronary T-wave syndrome "or "widow maker"(1).

The Wellens syndrome is defined as ECG changes specific for the T waves in the V2-V4 precordial leads that occur in patients with recent history of unstable angina, in most cases without chest pain and presenting cardiac necrosis biomarkers within normal range or slightly increased. The ECG changes mean there is a critical LAD stenosis in the proximal segment and that is a hazard of suffering a myocardial infarction.

The electrocardiographic criteria for diagnosing the Wellens syndrome are:

- Deep negative T waves in V2 and V3 (possibly in V1, V4, V5, V6 leads as well) or biphasic $T$ waves (initially positive deviation and negative afterwards) within the same leads

- associated with:

- isoelectric ST segment or presenting minimum elevation

- normal progression of the $\mathrm{R}$ wave or lacking $Q$ waves in the precordial leads There are 2 types of ECG in Wellens syndrome. Type $A$ is rare, in $25 \%$ of cases characteristic 


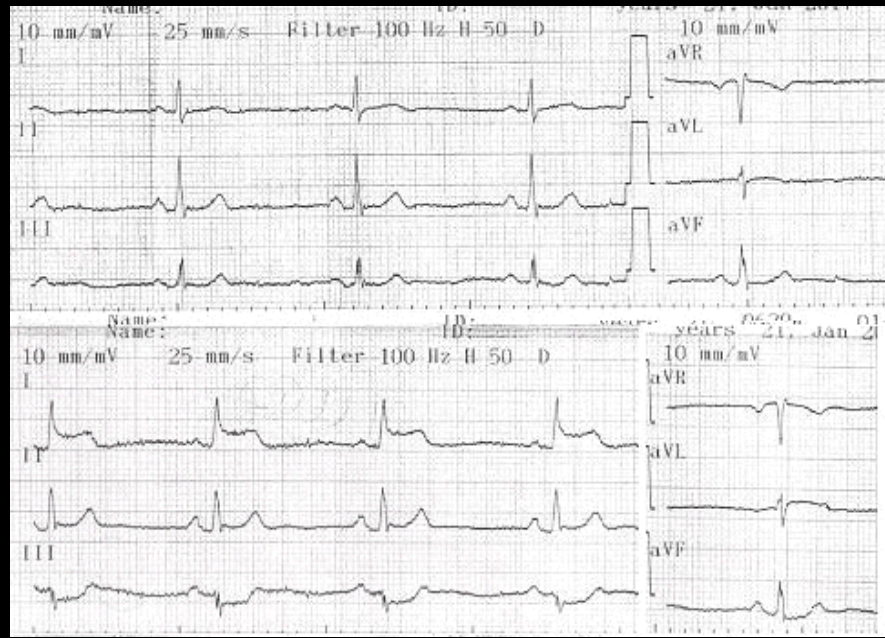

\section{Figure 2. Evolution of ECG changes in leads}

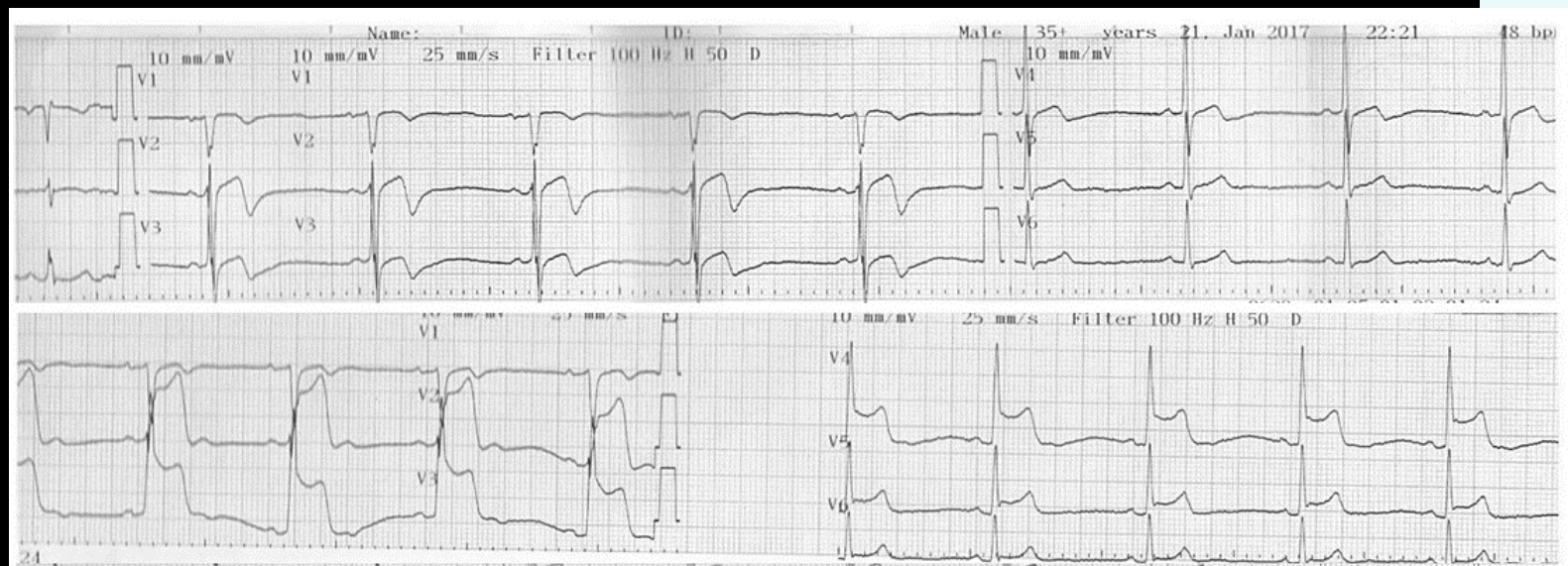

Figure 3. Evolution of ECG changes in precordial leads

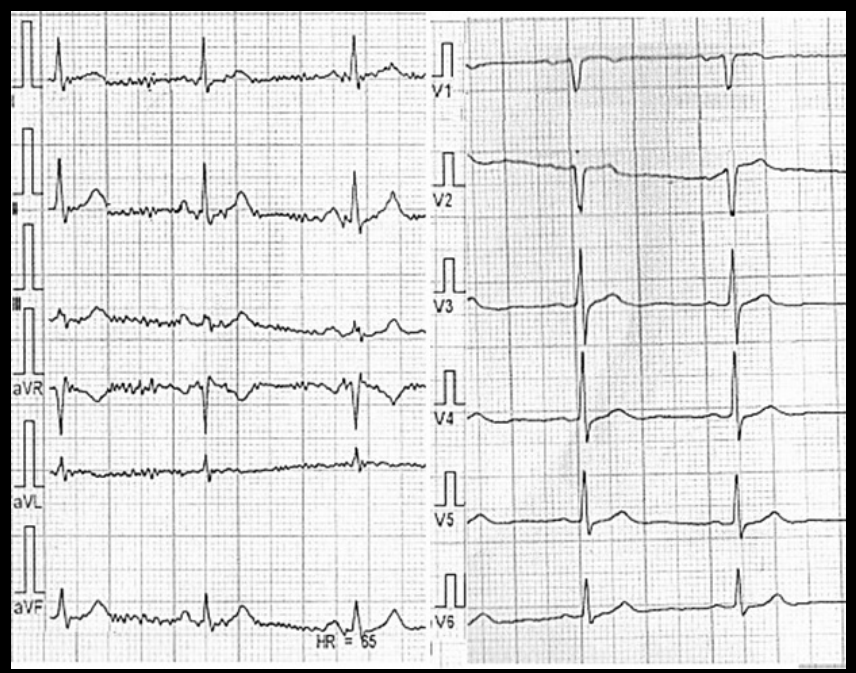

Figure 4. Normalized ECG trajectory prior to coronary angiography 


\section{INTERNAL}

\section{Clinical cases}

for biphasic $T$ waves presenting initially positive deviation and negative afterwards. The B type, which is more frequent, appears in $75 \%$ of cases, and the ECG presents deep and symmetrically negative $\mathrm{T}$ waves in the V2-V4 precordial leads (Figure 7$)^{(2)}$. It is extremely important to identify the Wellens syndrome because the ECG changes indicate a progressive ischemia, caused by an unstable atherosclerotic plaque located in the proximity of LAD artery. Without revascularization treatment consisting in angioplasty which is the election treatment ${ }^{(3,4)}$ most of the times it progresses rapidly to an extensive myocardial infarction. The ischemic cascade consists of a sequence of changes that take place during the first seconds after coronary occlusion and it begins with disorders of ventricular relaxation, followed by diminished contractility, increase of filling pressure and then, approximately 20 seconds later with display of electrocardiographic changes. Chest pain emerges late during the ischemic cascade, after the ECG changes and sometimes it may not appear at all. Without treatment, this silent ischemia associated to unstable angina has poor prognosis and high risk of cardiovascular events.

\section{Conclusions}

The particularity in this case is the rapid electrocardiographic progression, from Wellens syndrome to transmural ECG lesion, followed by a normalization of the ECG trajectory in a patient suffering from angina de novo. The anatomic base in the coronary syndrome was the proximal, subocclusive, LAD stenosis due to an unstable plaque. It is remarkable that the patient remained asymptomatic during the entire time of these dynamic changes in the ECG, and that enhances the necessity of strict electrocardiographic monitoring of patients suffering from angor de novo.

\section{Bibliography}

1. Minner B, Hart EH. Wellens syndrome. StatPearls Publishing; 2019: https://knowledge.statpearls.com/ chapter/0/31330?utm_source=pubmed. Visited online on 2019/05/21.

2. https://litfl.com/wellens-syndrome-ecg-library Visited online on2019/05/21.

3. Coutinho Cruz M, Luiz I, Ferreira L şi colab. Wellens' Syndrome: A Bad Omen. Cardiology. 2017;137(2):100103.

4. Flores Umanzor EJ, Vannini L, San Antonio $R$ şi colab. Wellens' syndrome. Intern Emerg Med. 2017 March;12(2):267-268. 

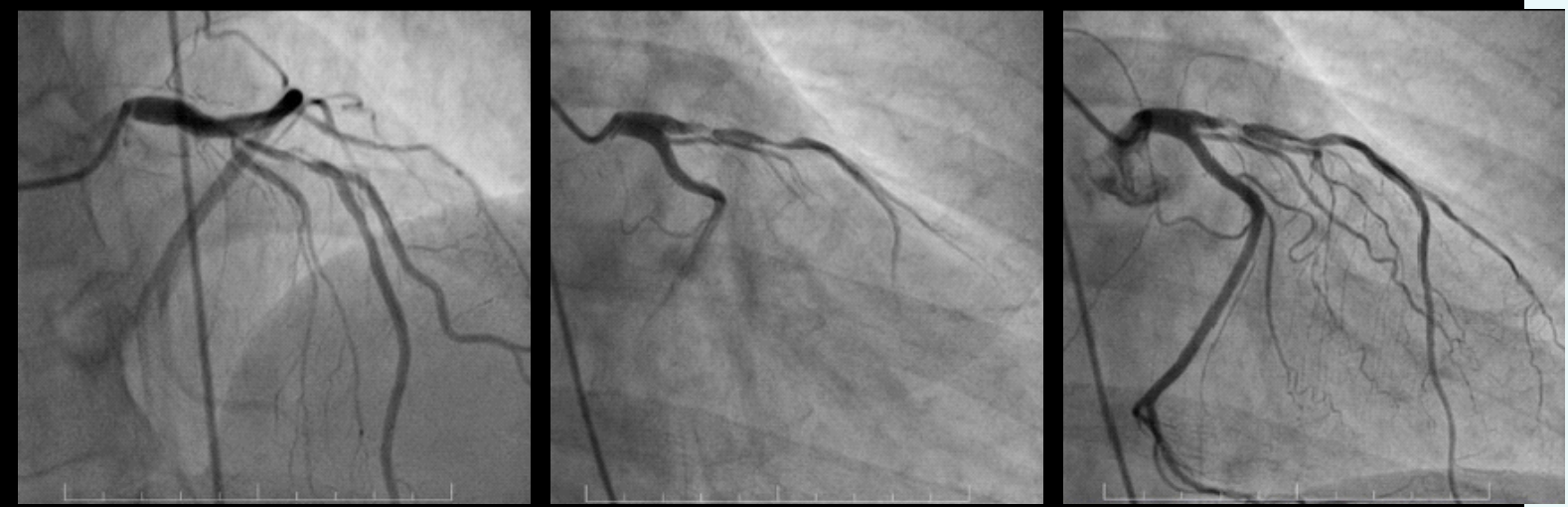

Figure 5. Coronary angiography: proximal left anterior descending artery stenosis
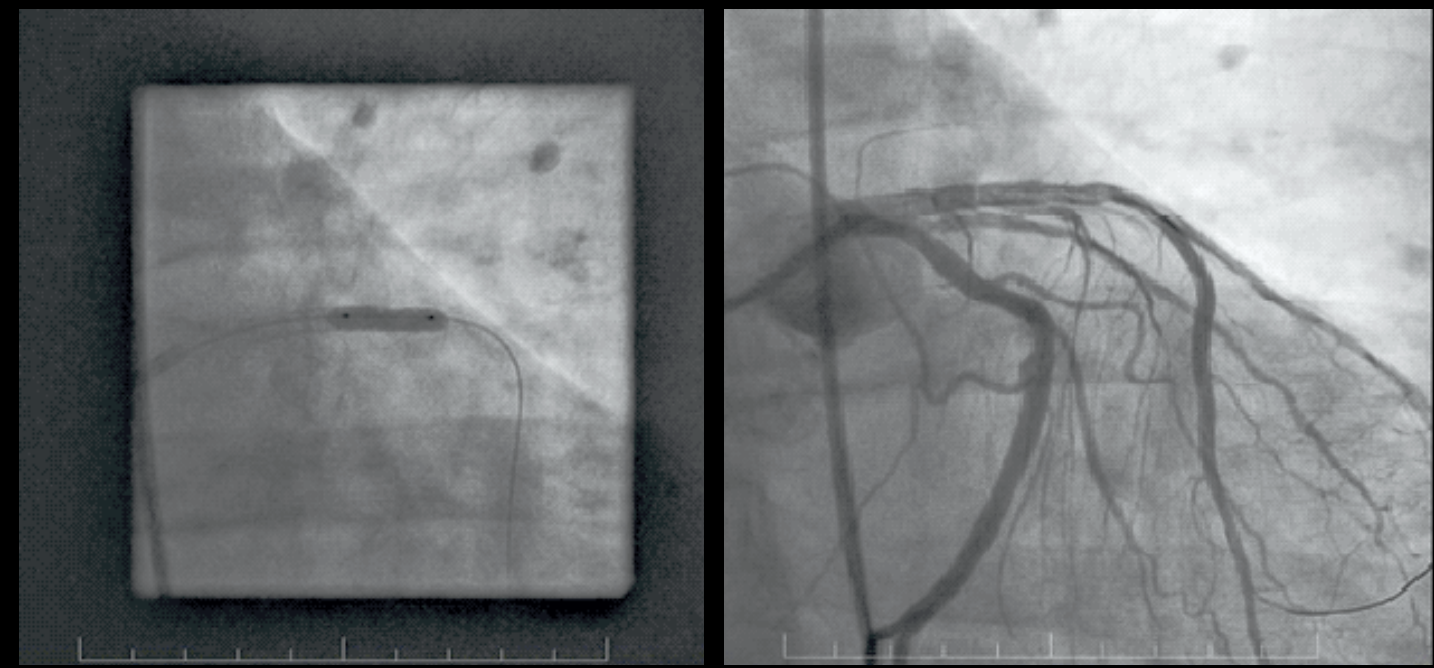

Figure 6. Coronary angiography: drug-eluting stent in left anterior descending artery

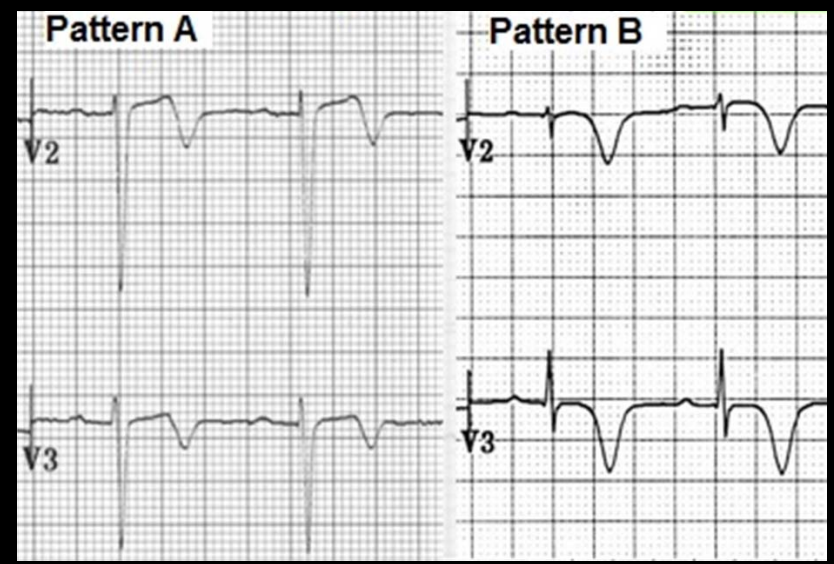

Figure 7. ECG patterns in Wellens syndrome (Pattern A - 25\%, pattern B - 75\%)(2) 